\title{
IMPORTANCE OF THE OXIDATION REACTION OF SODIUM METAPERIODATE FOR SPECTROPHOTOMETRIC ASSAY OF RESERPINE
}

\section{D.K.Singh^ and Archana Sahu}

Department of Chemistry, H. B. Technological Institute, Kanpur- 208002 (India)

\begin{abstract}
A new simple, accurate and reasonably sensitive spectrophotometric method is described for the determination of reserpine based on the oxidation with sodium metaperiodate in the presence of acetic acid and coupling with 3-methyl-2-benzo thiazolinone hydazone hydrochloride (MBTH) to form highly blue coloured product showing maximum absorbance at $630 \mathrm{~nm}$. Beer's law is obeyed in the range 0.2$1.6 \mu \mathrm{g} \mathrm{ml}^{-1}$. The relative standard deviation was found to be less than $1 \%$. The proposed method can be applied for the estimation of reserpine in tablets with no evidence of interference from excipients.
\end{abstract}

\section{Keywords}

Reserpine, spectrophotometry, sodium metaperiodate, 3-methyl-2-benzo thiazolinone hydrazone hydrochloride.

\section{Introduction}

The pharmaceutical properties of Rauwolfia alkaloids are mainly due to the presence of indole nucleaus, which have been extensively used as active 
ingredients in the pharmaceutical preparations [1]. Reserpine and rescinnamine are the two principal components of reserpine class and are known to have potent transquilizer, and sedative and antihypertensive action [2]. Literature survey reveals that a little attention was paid in developing the visible spectrophotometric methods [3-5]. A number of analytical methods have been proposed for the determination of reserpine based on voltametry [6], spectrofluorometry [7], high performance liquid chromatography [8-10], gas chromatography [11], room temperature phosphometry $[12,13]$, flow injection chemiluminescence [14] and polarography [15].

The proposed method is successfully applicable for the determination of reserpine in pure or pharmaceutical formulations with good accuracy and precision. The results are comparable with those given by official method (BP).

\section{Experimental}

\subsection{Apparatus}

A thermostatically controlled water bath and Bausch and Lomb Spectronic-20 with quartz cells of $1 \mathrm{~cm}$ optical path length were used for heating and absorbance measurements, respectively.

\subsection{Materials}

Reserpine (Himedia, India) and its pharmaceutical formulations were obtained from commercial sources.

\subsection{Reagents}

Sodium metaperiodate and MBTH were obtained from Merck. All other reagents and solvents used were of analytical grade. Sodium metaperiodate solution $\left(1 \times 10^{-2} \mathrm{M}\right)$ and $\mathrm{MBTH}\left(1 \times 10^{-2} \mathrm{M}\right)$ were prepared in double distilled water and kept in dark bottles to protect from light. 


\subsection{Preparation of standard solutions}

The stock solution of reserpine was prepared in a $100 \mathrm{ml}$ standard flask by dissolving $10 \mathrm{mg}$ of reserpine in methanol $(\sim 10 \mathrm{ml})$ and diluted to mark with double distilled water. Working solutions were prepared by appropriate dilution of the stock solution.

\subsection{Construction of calibration curve}

Aliquots of the standard solutions of reserpine $\left(10 \mu \mathrm{g} \mathrm{ml} \mathrm{m}^{-1}\right)$ in the concentration range 5-50 $\mu \mathrm{g}$ were transferred into a series of $25 \mathrm{ml}$ standard flasks. To each flask, $1 \mathrm{ml}$ of $\mathrm{NalO}_{4}(0.01 \mathrm{M})$ and $0.5 \mathrm{ml}$ acetic acid $(0.1 \mathrm{M})$ were added. The solutions were diluted with double distilled water $(\sim 10 \mathrm{ml})$ and kept in a boiling water bath for $10 \mathrm{~min}$. Then, $1 \mathrm{ml}$ of MBTH solution (0.01 M) was added and further heated for $5 \mathrm{~min}$. The solutions were cooled to room temperature and the volume was made up to the mark with distilled water. The absorbance of solutions was measured at $630 \mathrm{~nm}$ against a reagent blank prepared and treated similarly.

\subsection{Analysis of reserpine tablets}

An accurately weighed amount of powdered tablets equivalent to $5 \mathrm{mg}$ of the drug was dissolved in methanol $(\sim 10 \mathrm{ml})$. The solution was filtered through a Whatmann No.41 filter paper, which was then washed with about $10 \mathrm{ml}$ methanol. The filtrate and washings were collected into a $100 \mathrm{ml}$ standard flask and diluted to mark with double distilled water. A volume of later solution was diluted with double distilled water to obtain a solution equivalent to $10 \mathrm{\mu g} \mathrm{ml}^{-1}$ of the drug and then subjected to analysis as directed under construction of calibration curve.

\section{Results and Discussion}

The method involves the oxidation of reserpine with sodium metaperiodate in acidic medium followed by coupling with MBTH reagent. The blue coloured product 
formed has a $\lambda_{\max }$ at $630 \mathrm{~nm}$. This wavelength was used for all subsequent measurements. The absorption spectrum of the reaction products formed is shown in Fig.1.

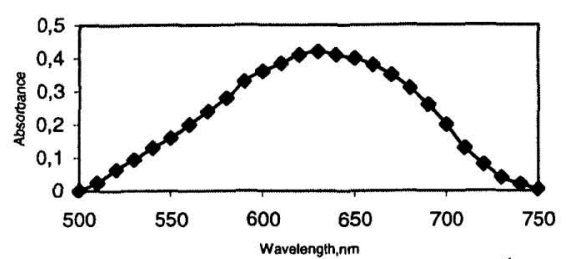

Wavelength, $n \mathrm{~m}$
Fig. 1. Absorption spectrum of reserpine $\left(0.8 \mu \mathrm{g} \mathrm{ml}^{-1}\right)$

containing $1 \mathrm{ml}$ of each of sodium metaperiodate $(0.01 \mathrm{M})$ and MBTH $(0.01 \mathrm{M})$ and $0.5 \mathrm{ml}$ of acetic acid $(0.10 \mathrm{M})$.

The corresponding reagent blank has practically negligible absorbance at this wavelength. The oxidation of reserpine with sodium metaperiodate in acidic medium is probably similar to the oxidation of reserpine with $\mathrm{Ce}$ (IV) sulphate [7]. The oxidized product couples with MBTH reagent. $A$ tentative reaction mechanism may be illustrated as given below in scheme 1 .<smiles>COC(=O)C1C2CC3c4[nH]c5cc(OC)ccc5c4CCN3CC2CC(OC(=O)c2cc(OC)c(OC)c(OC)c2)C1OC</smiles>

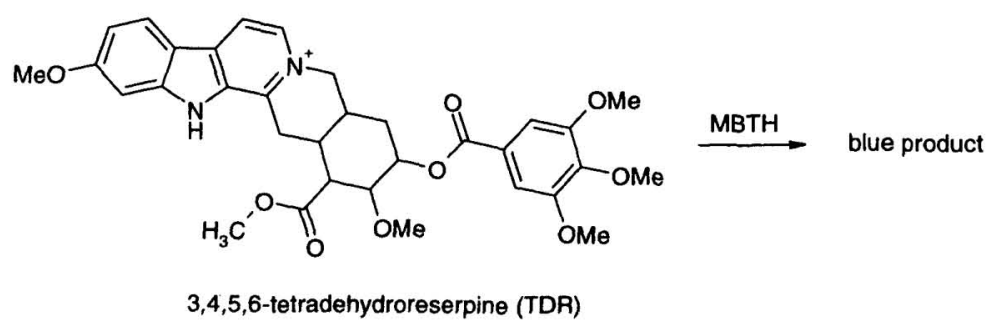




\subsection{Effect of variables}

The reaction conditions were established by varying one parameter at a time and keeping others constant. Effect of concentration of sodium metaperiodate / MBTH / acetic acid on absorbance, keeping fixed concentration of reserpine was investigated. Maximum and constant absorbance was found with sodium metaperiodate $(0.0004 \mathrm{M}), \mathrm{MBTH}(0.0004 \mathrm{M})$ and acetic acid $(0.002 \mathrm{M})$, and were therefore, adopted as optimal. A maximum and constant absorbance was observed after 10 min heating at the temperature of boiling water bath.

\subsection{Analytical features}

The Beer's law limits, the molar absorptivity and Sandell's sensitivity values were evaluated. Regression analysis of Beer's law plots revealed a good correlation. The plot of the absorbance versus concentration showed a zero intercept, and can be described by the regression equation

$$
Y=a+b X
$$

Where, $\mathrm{Y}$ is the absorbance of $1 \mathrm{~cm}$ layer, $\mathrm{b}$ is the slope, $\mathrm{a}$ is the intercept obtained by a least square method [16]. The results are summarized in Table 1. The low relative standard deviation values for the analysis of six replicates of reserpine indicate good precision and accuracy of the proposed method.

Tab. 1. Optical characteristics, precision and accuracy data for reserpine

\begin{tabular}{|l|c|}
\hline \multicolumn{1}{|c|}{ Parameters } & Values \\
\hline$\lambda_{\max }(\mathrm{nm})$ & 630 \\
\hline Beer's Law Limits $\left(\mu \mathrm{g} \mathrm{ml}^{-1}\right)$ & $0.2-1.6$ \\
\hline Molar absorptivity $\left(\mathrm{mol}^{-1} \mathrm{~cm}^{-1}\right)$ & $3.192 \times 10^{5}$ \\
\hline Sandell sensitivity $\left(\mu \mathrm{g} \mathrm{cm}^{-2} / 0.0001\right.$ absorbance unit) & 0.0019 \\
\hline Regression line equation $(\mathrm{Y})^{\star}$ & \\
\hline
\end{tabular}




\begin{tabular}{|l|c|}
\hline Slope $(\mathrm{b})$ & 0.5225 \\
\hline Intercept $^{*}(\mathrm{a})$ & 0.0045 \\
\hline Correlation coefficient $(\mathrm{r})$ & 0.9997 \\
\hline Relative standard deviation $(\%, \mathrm{n}=6)$ & 0.94 \\
\hline
\end{tabular}

* Absorbance concentration $\left(\mu \mathrm{g} \mathrm{ml}^{-1}\right)$ relation

\subsection{Interference studies}

In order to assess the analytical applications of the proposed method, the effect of excipients that often accompany reserpine in various pharmaceutical formulations were studied by adding different amounts of these excipients to known amounts of reserpine $\left(10 \mu \mathrm{g} \mathrm{ml}^{-1}\right)$. It was observed that the talc, glucose, dextrose, magnesium streate, lactose, starch and gelatin did not interfere up to the levels found in dosage forms.

\subsection{Application of the method}

The applicability of the proposed method was examined for the assay of pharmaceutical formulations. The results of the assay of reserpine in tablets (Table 2) were comparable with the quoted values and those obtained by official method [17].

Tab. 2. Analysis of reserpine in pharmaceutical formulations

\begin{tabular}{|c|c|c|c|}
\hline \multirow[t]{2}{*}{ Drug } & \multirow[t]{2}{*}{$\begin{array}{l}\text { Label claim } \\
\text { mg/tablet }\end{array}$} & \multicolumn{2}{|c|}{$\begin{array}{c}\% \text { Recovery }^{a} \pm S D^{a} \text {, and comparison with } \\
\text { the official method }\end{array}$} \\
\hline & & Official method & Proposed method \\
\hline Adelphane & 0.1 & $\begin{array}{c}99.85 \pm 0.77 \\
(2.78)^{\mathrm{b}} \\
(6.36)^{\mathrm{b}}\end{array}$ & $\begin{array}{l}100.81 \pm 1.11 \\
F=1.21 \\
t=1.15\end{array}$ \\
\hline
\end{tabular}




\begin{tabular}{|c|c|c|c|}
\hline $\begin{array}{c}\text { Adelphane } \\
\text { (Esidrex) }\end{array}$ & 0.1 & $99.53 \pm 0.95$ & $\begin{array}{l}100.03 \pm 1.05 \\
F=0.93 ; \\
t=1.07\end{array}$ \\
\hline Serpasil & 0.25 & $99.60 \pm 1.11$ & $100.00 \pm 0.91$ \\
& & & $F=1.05 ;$ \\
& & & $t=1.16$ \\
\hline
\end{tabular}

${ }^{a}$ Average of six determinations.

${ }^{b}$ Values in parentheses are the theoretical values at $p=0.05$.

\subsection{Statistical analysis of the results in comparison with the official method}

The performance of the proposed method was compared statistically in terms of the student t-test and variable ratio F-test. At $95 \%$ confidence level, the calculated $t-$ and $F$ - values do not exceed the theoretical values. It is found from Table 2 that there is no significant difference between the proposed and official methods. From an analytical point of view it is concluded that the described procedure is useful for the routine analysis of reserpine in pure and pharmaceutical dosage forms. The reagents used are cheaper and readily available, and the procedure does not involve any critical reaction conditions, such as extraction or tedious sample preparation.

\section{Acknowledgements}

The authors thank Head, Department of Chemistry and Director, H.B. Technological Institute, Kanpur for the provision of research facilities.

\section{References}

[1] Katzung B G, In: Farmacologia Basica e Clinica. 5th ed. Guanabara Koogan, Rio de Janeiro. 1994:114.

[2] Goldman L S, Gilman A, In: The Pharmacological Basis of Therapeutics. 4th ed., Macmillan, New York, 1970.

[3] Varma S R, Calatatud J M, Mottola H A.

Continuous Flow Determination of Reserpine by Oxidation with 
Periodate Ion and Catalysis by Manganese Dioxide Reactor.

Anal. Chim. Acta, 1990; 233: 235-241.

[4] Manzar A, Qazi N, Hussein I, Azhar I.

Spectrophotometric Determination of Some Indole Drugs.

J. Chem. Soc. Pak. 2000; 22:111-114.

[5] Blazneavskii N E, Batalov A I.

Oxidimetric Determination of Alkaloids Based on the $\mathrm{N}$-oxidation with Peroxycarboxylic acid.

J. Anal. Chem. 1999; 54: 78-80.

[6] Wang J, Ozsoz M.

Hydrophobic Stripping Voltametry of Antihypertensive Drugs at Lipid Modified Electrodes.

Analyst 1990; 115: 831-834.

[7] Miguel S, Sanchez-Aibar Juan J.

Spectrofluorometric Determination of Reserpine by Oxidation with Cerium (IV) Sulphate.

Analyst 1996; 121: 1581-1582.

[8] Cieri Ugo R.

Determination of Reserpine and Chlorothiazide in Commercial Tablets by LC with Fluorescence and UV Absorbance Detector in Series.

J. AoAc Int. 1995; 78:1384-1387.

[9] Yakimov S A, Tuzova T P, Kuzovkina I N, Wulfson A N, Miroshnikov Al.

Determination of Indole Alkaloids from R. Serpentina and R.Vomitoria by HPTLC and HPLC.

J. Chromatogr A 1995; 704: 357-362.

[10] Ke Jing, Yancey M, Zhang S, Lowes S, Henion J.

Quantitative Liquid Chromatographic Tendam Mass Spectrometric Determination of Reserpine in FVB/N Mouse Plasma Using a Chelating Agent (disodium EDTA) for Releasing Protein Bonded Analytes During 96 Well Liquid-Liquid Extraction.

J. Chromatogr A 2000; 742: 369-380.

[11] Disimone L, Portelli G, Del Giudice M R, Gatta F, Settimj G.

Application of a New Method for the Determination of Reserpine and Rescinnamine to the Control of Chemical Drugs.

Farmaco 1980; 35: 223-232

[12] Aucelio R Q. Campiglia A D.

Solid Surface Room Temperature Phosphometry Analysis of Reserpine in Pharmaceutical Formulations.

Talanta 1994; 41: 2131-2136.

[13] Arruda A F, Aucelio R Q.

Room Temperature Phosphometry for the Selective Determination of 
Yohimbine in Presence of Reserpine like Indolic Alkaloids.

Anal. Sci. 2002; 18: 831-834.

[14] Qiao-Hua W, Huisheng Z, Qiang er W, Guo-War C.

New Flow Injection Chemiluminescence's System for the Determination of Reserpine.

Fenxi Kexue Xuebao 2001; 17: 501-504.

[15] Taira A, Smith DE.

Diffential Pulse and ac Polarography of Reserpine Using Aprotic Organic Solvent System.

J. Assoc. Off. Anal. Chem. 1978; 61: 941-948.

[16] Spiegel M R. In: Theory and Problems of Probability and Statistics: Mc Graw-Hill. New York, 1975: 215.

[17] British Pharmacopoeia, H. M. Stationary office, London, 2000. 